\title{
The Effect of Electroacupunture on the Percentage of Lymphocyte Count on the Peripheral Blood Smear of C3H Mice Breast Adenocarcinoma Model
}

\author{
Rizki Kamalia ${ }^{1}$, Hasan Mihardja ${ }^{1}$, Adiningsih Srilestari ${ }^{1}$, Atikah C Barasila², \\ Husniah Rubiana Thamrin Akib ${ }^{3}$ \\ ${ }^{1}$ Department of Medical Acupuncture, Faculty of Medicine, University of Indonesia. ${ }^{2}$ Department of Histology, \\ Faculty of Medicine, University of Indonesia. ${ }^{3}$ Medical Acupuncture Specialist Medical Association.
}

\section{ARTICLE INFO}

\section{Article history}

Received 24 January 2018

Received in revised form 4 Mei 2018

Accepted 14 Meil 2018

\section{Keywords:}

Breast cancer; electroacupuncture; increasingthe percentage of lymphocytes.

\section{Kata Kunci:}

elektroakupunktur; kanker payudara; peningkatan persentase limfosit.

\footnotetext{
* Corresponding author: Hasan Miharja Department of Medical Acupuncture, Faculty of Medicine, University of Indonesia, Jalan Salemba Raya No.6, RW.5, Kenari, Senen, Central Jakarta, Jakarta Capital Special Region 10430, Indonesia. hasanmihardja@gmail.com
}

\begin{abstract}
Background: Breast cancer patients often experience decreased the immune system such as a decreased of lymphocytes, which can increase mortality. Acupuncture is expected to be a therapeutic option to increase lymphocyte because current pharmacological therapy is very expensive with the risk of adverse event. This study aims to prove the action of Electroacupuncture (EA) as an immunomodulator for cellular immunity by increasing the percentage of lymphocytes of Peripheral Blood Smear (PBS) in C3H mice of breast adenocarcinoma model.
\end{abstract}

Methods:Laboratory experimental study with post test only controls group design involving twenty PBS preparations taken from $20 \mathrm{C} 3 \mathrm{H}$ mice of breast adenocarcinoma models divided into 4 groups. Group K with no EA treatment, group P1 was given 1 time EA treatment, group $P 2$ was given 2 times EA treatment and P3 was given 3 times EA treatments (with seven days interval). EA stimulation was performed at ST36 Zusanli, BL18 Ganshu, BL20 Pishu with frequency of $2 \mathrm{~Hz}$ for 15 minutes.

Result:The mean weight of mice was $23.90 \pm 3.03$ gr in control group, $25.40 \pm 1.54$ gr in P1 group, $27.00 \pm 3.87$ gr in P2 group and $25.90 \pm 5.83$ gr in P3 group, with most of them were female mice. The mean volume tumor in mice of control group was $14.49 \pm 2.75 \mathrm{~mm}^{3}, 16.72$ $\pm 6,40 \mathrm{~mm}^{3}$ in P1 group, $20.18 \pm 5.94 \mathrm{~mm}^{3}$ in $\mathrm{P} 2$ group and $22.07 \pm 6.51 \mathrm{~mm}^{3}$ in $\mathrm{P} 3$ group. The mean percentage of lymphocyte was $44.20 \pm 15.72$ in control group, $43.00 \pm 11.70$ in P1 group, $49.60 \pm 7.02$ in $\mathrm{P} 2$ group and $43.20 \pm 13.10$ in $\mathrm{P} 3$ group. The correlation between the number of electro-acupuncture treatments on the number of lymphocytes in the treatment group were compared to the control group with $p=0.811$.

Conclusions: Research acupuncture on cancer management has been done and provided good result. Acupuncture in particular EA has benefits in improving immunity by affecting lymphocyte enhancement. Acupuncture can be considered as adjuvant therapy in cancer patients breast.

\section{ABSTRAK}

Latar Belakang: Pada pasien kanker payudara sering terjadi penurunan sistemimun antara lain menurunnya limfosit, yang dapatm eningkatkan angka kematian. Akupunktur diharapkan dapat menjadi pilihan terapi untuk meningkatkan limfosit karena terapi farmakologi saat ini harganya sangat mahal dengan resiko efek samping. Penelitian ini bertujuan untuk membuktikan bahwa tindakan elektroakupunktur (EA) dapat berefek sebagaii mmunomodulator terhadap imunitas seluler dengan meningkatkan persentase limfosit sediaan apus darah tepi (SADT) pada mencit C3H model adenokarsinoma payudara.

Metode: Penelitian eksperimental ini dilakukan dengan post test only control group design terhadap dua puluh sediaan apus darah tepi yang diambil dari 20 mencit $\mathrm{C} 3 \mathrm{H}$ model adenokarsinoma payudara. Kelompok studi dibagi menjadi 4 kelompok yaitu Kelompok $\mathrm{K}$ tidak diberi perlakuan EA, kelompok P1 dilakukan EA 1 kali, kelompok P2 dilakukan EA 2 kali dan P3 dilakukan EA 3 kali. Tindakan EA dilakukan pada titik ST36 Zusanli, BL18 Ganshu, BL20 Pishu dengan frekuensi $2 \mathrm{~Hz}$ selama 15 menit. 
Hasil: Rerata berat mencit adalah $23,90 \pm 3,03$ g pada kelompok kontrol, $25,40 \pm 1,54$ g pada kelompok $\mathrm{P} 1,27,00 \pm 3,87 \mathrm{~g}$ pada kelompok P2 dan 25,90 $\pm 5,83$ g kelompok P3, sebagian besar terdapat mencit betina. Rerata volume tumor pada mencit kelompok kontrol adalah $14,49 \pm 2,75 \mathrm{~mm}^{3}, 16,72 \pm 6,40 \mathrm{~mm}^{3}$ pada kelompok $\mathrm{P} 1,20,18 \pm 5,94 \mathrm{~mm}^{3}$ pada kelompok $\mathrm{P} 2$ dan 22,07 $\pm 6,51 \mathrm{~mm}^{3}$ dalam P3. Rerata persentase limfosit adalah 44,20 \pm 15,72 pada kelompok kontrol, $43,00 \pm 11,70$ pada kelompok $\mathrm{P} 1$, $49,60 \pm 7,02$ pada kelompok $P 2$ dan $43,20 \pm 13,10$ pada kelompok P3. Korelasi antara jumlah terapi elektro-akupunktur pada jumlah limfosit pada kelompok perlakuan dibandingkan dengan kelompok kontrol $p=0,811$.

Kesimpulan: Penelitian akupunktur pada manajemen kanker telah banyak dilakukan dan memberikan hasil yang baik. Akupunktur khususnya elektroakupunktur memiliki manfaat dalam meningkatkan sistim imun dengan mempengaruhi peningkatan limfosit. Akupunktur diharapkan dapat menjadi pilihan sebagai terapi adjuvant pada pasien kanker payudara.

\section{BACKGROUND}

Breast Cancer $(\mathrm{BC})$ is the second most common cancer in women after cervical cancer. BC becomes a problem because the etiology is definitely not known so it is difficult to prevent. BC is often detected by the time it enters an advanced stage and may cause pain or disability. ${ }^{1}$ In 2012, based on the Global Burden of Cancer (GLOBOCAN) data, the International Agency for Research on Cancer (IARC) has 14,067,894 new cases of cancer and $8,201,575$ deaths from cancer worldwide, with lung cancer and $B C$ being the leading cause of death. ${ }^{2,3}$ In the United States, an estimated of 235,030 new cases of BC are diagnosed in 2014. ${ }^{2}$ Based on data from 2013 Basic Health Research (Riskesdas) in Indonesia, the prevalence of cancer in the population of all ages was at $1.4 \%$, with the highest prevalence in Yogyakarta Province, which is $4.1 \%{ }^{3}$

Breast cancer as well as other malignancies will stimulate the immune response of both cellular and humoral immunity. Cancer cells express Specific Tumor Antigens (STA) that are recognized by the immune system as foreign matter. There are several effector mechanisms that contribute to cancer cells, Cytotoxic $T$ Lymphocytes (CTL), Natural Killer cell (NK cells), macrophages and antibodies. The immune response to cancer cells begins with the introduction of cancer cell antigen by Lymphocyte $T$ through mechanism of presenting antigen by macrophage cells, then activating effector mechanism to eliminate cancer cells. ${ }^{4}$

One of the attempts to overcome cancer is by modulating the cellular immune system, especially increasing the role of macrophage cells and T helper (Th) lymphocytes as interferon-gama (IFN- $\gamma$ ) -curring immunocompetent cells. Increased IFN- $\gamma$ will activate NK and CTL cells that will destroy cancer cells without causing side effects in patients.

EA is defined as an acupuncture procedure using electrical stimuli for promotive, palliative, curative and rehabilitative purposes. ${ }^{5}$ EA is used for analgesic effects or overcoming pain, relaxation, improving blood circulation, and overcoming muscle disorders, has an immunomodulatory effect by affecting the autonomic nervous system (ANS) and the hypothalamicpituitaryadrenal (HPA) axis. ${ }^{6,7}$ Based on the research, EA at point ST36, BL18 and BL20 can increase the percentage of lymphocytes that can increase the body's ability to fight cancer. ${ }^{8}$

$B C$ will stimulate cellular or humoral immune responses. This is because cancer cells will express molecules that the immune system will recognize as foreign. CTL cells, NK cells, macrophage cells and antibodies are the immune response that plays a role against cancer. The immune response to cancer cells begins with the introduction of Antigen Presenting Cell (APC) of cancer cells by $T$ lymphocytes through the mechanism of antigen presentation by macrophage cells, then immune response activates in the form of lymphocyte proliferation and activates effector mechanism to eliminate cancer cells.

Immune surveillance is a mechanism used by the body to react against any antigen expressed by cancer cells. NK cells, CTL and macrophages play a major role in immune surveillance tumors. ${ }^{9}$

Lymphopoiesis is the growth and maturation of lymphocytes. Nearly $20 \%$ of normal bone marrow consists of developing lymphocytes. After maturation, lymphocytes enter the blood vessels, circulate and then converge in the lymph nodes. The time needed by stem cells to become lymphocytes is $7-11$ days. ${ }^{10}$ Examination of leukocyte count is often neglected if the number of leukocytes in the blood is normal and there are no hematologic abnormalities either clinical or laboratory. Although the number of leukocytes is still within normal limits, there are many disorders such as inflammation, malignancy and immunologic abnormalities that can cause changes in the percentage of this type of leukocytes. The peripheral blood smear is a microscopic examination, to observe the morphology of blood cells and other components that can provide considerable and useful information to know a person's hematologic state. ${ }^{10}$

Acupuncture comes from Latin, acus, "needle", and pungere, "puncture" or in Chinese is called zhen jiu where zhen (puncture) and jiu (burn), otherwise known as "acupuncture moxibustion" therapy which is a therapeutic techniques of thrusting needles or heating to the acupuncture points of the body. The definition and characterization of these points is standardized by the World Health Organization (WHO). 
EA is defined as acupuncture puncture stimulation using electrical stimuli for promotive, preventive, curative and rehabilitative purposes. ${ }^{5}$ Animal experiments show that EA stimuli can modulate the immune response. ${ }^{7}$ Other research proves that EA can relieve pain in cancer, stimulate the body's immune function including increasing blood counts, increasing lymphocytes and increasing NK cell activity. ${ }^{11}$ The effects of low frequency EA appear after 30 minutes and are adequate between 30 minutes and 45 minutes. In cancer, EA can modulate the immune system because EA can stimulate the growth of leukocytes (granulocytes and lymphocytes) through HPA axis, and increase the activation of T lymphocytes and NK cells so that the immune function of cancer patients increases.

This study aims to prove the role of EA as an immunomodulator in $\mathrm{C} 3 \mathrm{H}$ mice breast adenocarcinoma model. Stimulation of EA is thought to increase the PBS lymphocytes so BC cells can be reduced.9,10,12-14 The results of this study are expected to provide information to the wider community that acupuncture can be used as a therapeutic option to increase the percentage of lymphocytes in BC.

\section{METHODS}

This laboratory experimental research with post test only control group design was conducted in histology department laboratory FKUI from March to June 2017. This study starts from PBS examination and analysis. Mice and treatments are part of Mihardja's research entitled "The Influence of Electroacupuncture at the point ST36, BL18, BL20 on levels of Interferon Gamma, mitotic image, apoptosis and weight of breast cancer Adenocarcinoma Mice C3H and correlation with number of actions". The estimation of minimum sample size was calculated using the formula for a correlation study. ${ }^{14}$ Subjects were obtained using computer-based random table.

All $\mathrm{C} 3 \mathrm{H}$ mice successfully modeled adenocarcinoma of the breast, reaching the size of $1 \mathrm{~cm}$ tumor. There is no anatomic abnormalities in the area to be done acupuncture and after preparation was made, the color is well were included in this study. The exclusion criteria were not growing tumors in mice, mice in an unhealthy state and preparations can not be read.

In this study, C3H mice used anatomical, physiologically well-characterized traits as well as immunities similar to humans, ${ }^{8,15,16}$ available C3H mice injected Mice Mamilary Virus resulting adenocarcinoma of the breast as a tissue donor tumor to be injected into the recipient. Angus blood smear is divided into four groups: a). The controls were PBS mice $\mathrm{C} 3 \mathrm{H}$ breast adenocarcinoma model that did not get EA action, b). Group P1 is PBSmice $\mathrm{C} 3 \mathrm{H}$ breast adenocarcinoma model who got EA action once, c). Group P2 is PBS mice $\mathrm{C} 3 \mathrm{H}$ breast adenocarcinoma model who got EA action twice, d). Group P3 is PBSmice $\mathrm{C} 3 \mathrm{H}$ breast adenocarcinoma model that got EA action three times.

The research received approval from the ethics committee of animal care and use committe of PT. Bimana Indomedical R.01-16-IR.

Data were collected through weight examination of mice, tumor volume, sex of mice and blood sampling. Weight examination of mice, tumor volume and sex of mice were conducted to determine the characteristics of subjects. Blood sampling were conducted to determine percentage of lymphocytes. The mean percentage of lymphocytes was calculated based on the number of lymphocytes on the count of 100 leukocyte cells seen under a microscope with 400 times magnification. The peripheral blood smear preparations examined were made from $\mathrm{C} 3 \mathrm{H}$ mice of the dyestruched breast adenocarcinoma model on day 7 (P1 group), on the 14th day (group K, P2) and on the 21st day (P3 group). The calculation of lymphocyte obtained from the PBS leukocyte count examination was observed using the Olympus CX-21 brand light microscope, searched for the thinest, non-lumped pulse area, with $100 x$ initial magnification, then viewed with $200 x$ enlargement, up to 400x magnification. When it appears that blood cells are far apart or not accumulate, just start counting all types of leukocytes to 100 cells, then calculated the percentage of lymphocytes. The appearance of the PBS application under the microscope can be seen in Figure 1-3.

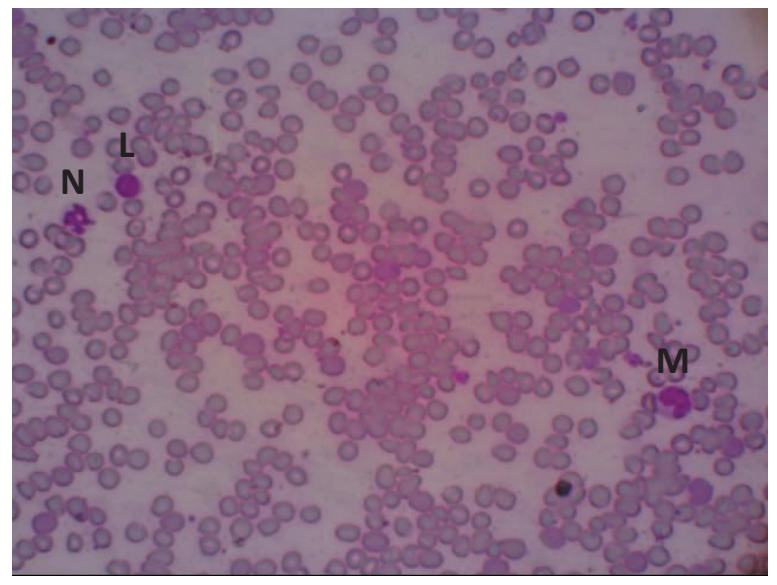

Figure 1. The appearance of the peripheral blood smear application under the microscope can be seen Lymphocytes (L), Neutrophils (N), Monocytes (M), magnification 400 times 


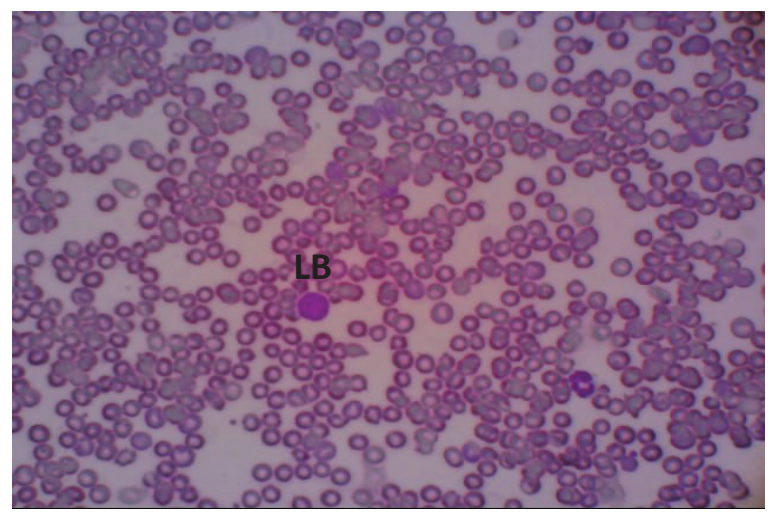

Figure 2. The appearance of the peripheral blood smear application under the microscope can be seen Big Lymphocyte (LB), magnification 400 times

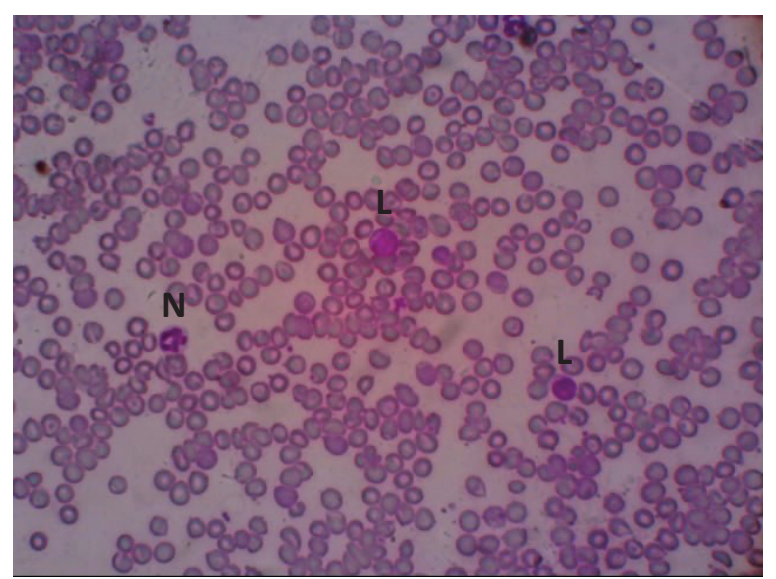

Figure 3. The appearance of the peripheral blood smear application under the microscope can be seen Lymphocytes (L), Neutrophils (N), magnification 400 times

\section{Statistical analysis}

Data was processed using the program Statistical Package for Social Sciences (SPSS) for Windows version 20. The normality of data distributions was analyzed using Shapiro-Wilk test. If $p<0.05$ data were normal distributed and were presented as mean \pm standar deviation, otherwise data were presented as median (minimum-maximum). Percentage of lymphocyte are analyzed by Anova test.

\section{RESULTS}

\section{Subjects characteristics}

The characteristics of the subjects were summarized in Table 1. The mean weight of mice were $23,90 \pm 3,03 \mathrm{~g}$ in control group, $25,40 \pm 1,54 \mathrm{~g}$ in $\mathrm{P} 1$ group, $27,00 \pm$ $3,87 \mathrm{~g}$ in $\mathrm{P} 2$ group and 25,90 $\pm 5,83 \mathrm{~g}$ P3 group, most of them were female of mice. The mean volume tumor in mice of control group were 14,49 $\pm 2,75 \mathrm{~mm}^{3}, 16,72 \pm$ $6,40 \mathrm{~mm}^{3}$ in $\mathrm{P} 1$ group, 20,18 $\pm 5,94 \mathrm{~mm}^{3}$ in $\mathrm{P} 2$ group and $22,07 \pm 6,51 \mathrm{~mm}^{3}$ in $\mathrm{P} 3$. The mean percentage of lymphocyte were 44,20 $\pm 15,72$ in control group, 43,00 \pm 11,70 in P1 group, 49,60 \pm 7,02 in P2 group and 43,20 \pm 13,10 in P3group (Table 2). In this study, we did not find significant correlation between between the number of electro-acupuncture treatments on the number of lymphocytes in the treatment group compared with the control group. (Table 3).

Table 1. The Characteristics of Research subjects

\begin{tabular}{|c|c|c|c|c|c|}
\hline \multirow[b]{2}{*}{ Basic Data } & \multicolumn{5}{|c|}{ Treatment } \\
\hline & $\begin{array}{c}C \\
(n=5)\end{array}$ & $\begin{array}{c}\text { P1 } \\
(n=5)\end{array}$ & $\begin{array}{c}\text { P2 } \\
(n=5)\end{array}$ & $\begin{array}{c}\text { P3 } \\
(n=5)\end{array}$ & Value $p^{*}$ \\
\hline 1. Weight (g) & & & & & 0,229 \\
\hline Average (SD) & $23,9(3,03)$ & $25,4(1,54)$ & $27,0(3,87)$ & $25,9(5,83)$ & \\
\hline Range & $19,7-28,0$ & $24,3-228,0$ & $23,4-32,2$ & $18,7-34,2$ & \\
\hline 2. Volume to $\operatorname{Max}\left(\mathrm{mm}^{3}\right)$ & & & & & 0,182 \\
\hline Average (SD) & $14,49(2,75)$ & $16,72(6,40)$ & $20,18(5,94)$ & $22,07(6,51)$ & \\
\hline Range & $10,21-17,52$ & $11,95-27,50$ & $11,18-27,27$ & $11,49-27,42$ & \\
\hline 3. Gender & & & & & 0,190 \\
\hline Male & 2 & 3 & 0 & 1 & \\
\hline Female & 3 & 2 & 5 & 4 & \\
\hline
\end{tabular}

Information: *) Based of the F Test (Variance Analysis),exept sex by Chi-square test. Source: Mihardja,H. (2016) 
Table 2. The mean value of the calculated lymphocyte percentage in each experimental group

\begin{tabular}{cc} 
Group & Mean \%(SD) percentage of lymphocyte count \\
\hline P1 & $43,00 \pm 11,705$ \\
P2 & $49,60 \pm 7,021$ \\
P3 & $43,20 \pm 13,103$ \\
Control & $44,20 \pm 15,723$ \\
\hline
\end{tabular}

Table 3. The correlation between the number of electro-acupuncture treatments on the number of lymphocytes in the treatmend group compared with the control group

\begin{tabular}{ccc} 
Group & Average (\%) & p* \\
\hline P1 & 43,00 & 0,811 \\
P2 & 49,60 & \\
P3 & 43,20 & \\
Control & 44,20 & \\
\hline
\end{tabular}

*Anova test

\section{DISCUSSION}

In this study, the weight of the mice used was between $23 \mathrm{gr}-25 \mathrm{gr} .{ }^{17}$ Due to the limitations of the study subjects, when the tumor has grown on one side without limiting the weight of the tumor volume achieved all inserted to the study. The subjects of the study were male $\mathrm{C} 3 \mathrm{H}$ mice that can grow adenocarcinoma of breast, it shows that breast cancer can occur in human beings both men and women. ${ }^{18,19}$

In the P1 group the number of lymphocytes is lower than the control, it proves that the cancer stimulates lymphocyte cells but with the administration of EA 1 times has not formed much due to the process of formation of lymphocytes to mature lymphocytes and circulated in the blood takes 7-11 days and this is in accordance with other previous research. ${ }^{9,20}$

In the $\mathrm{P} 2$ group of $\mathrm{C} 3 \mathrm{H}$ mice, the adenocarcinoma model of breast received EA action twice, obtained the mean percentage of lymphocytes $49,60 \%$, the highest among all groups although there was no statistically significant difference $(p=0.811)$. This suggests that EA may increase the percentage of lymphocytes in $\mathrm{C} 3 \mathrm{H}$ mice of breast adenocarcinoma model and as in other previous research, the lymphocyte increased on day eight. ${ }^{21}$

In the P3 group the number of lymphocytes has a higher mean than the P1 group but not as high as the mean P2 group, which means that the more EA the higher the number of stimulated lymphocytes, but facing cancer cells required more frequent EA action with a longer period of time, as in other previous study showed an increase in NK cells after 10 acupuncture treatments. ${ }^{22}$ It is also in accordance with the results of other previous research that conducted acupuncture every day for 21 days. $^{23}$

Selection of ST36 Zusanli points in previous studies has been shown that ST36 Zusanli can regulate immune system activity by affecting $T$ cells and B cells.[24,25] BL18 Ganshu can increase lymphocyte cell proliferation with increased $T$ cell mitosis, increase the formation of IFN- $\gamma$ and IL-4, stimulates macrophages to produce IFN- $\gamma$ and IL-12 and decrease cancer metastases in the liver. ${ }^{27,28}$ Acupuncture at BL20 Pishu in previous studies showed the increase of beta $(\beta)$ - endorphin production as well as the amount of activated T lymphocytes.[21] Studies using ST36 Zusanli, BL18 Geshu, BL20 Pishu for one month of acupuncture therapy showed increased NK cell activity. Previous study found that acupuncture increased the percentage of NK cells after therapy for 1-8 days by producing important IFN- $\gamma$ in immune mechanisms to remove cancer cells. ${ }^{21,26,28}$

In this study, the use of EA excitation technique with frequency of $2 \mathrm{~Hz}$, low frequency will stimulate opioid receptors $\mu$ and $\delta$ release $\beta$-endorphins that affect immune cells. ${ }^{27}$ In previous studies, both experimental animals and healthy volunteers, the use of low frequency EA and acupuncture manuals was proven to induce cytokines associated with opioid receptors and NK cell receptors. ${ }^{21,28}$

T lymphocytes play a very important role in controlling the growth of cancer cells. Cancer cells can cause interference or failure of the mechanisms of organ multiplication and homeostasis. This has an impact on the body's immune system. Examination count leukocyte type is often ignored, if the state of the leukocyte count in the blood is quite normal and there are no hematologic abnormalities both clinical and laboratory. Actually, although the number of leukocytes is still within normal limits, there are still many abnormalities such as inflammation, malignancy and immunologic abnormalities that can cause percentage changes in the leukocyte count type.

Conditions of breast cancer in the body will trigger the occurrence of resistance by the immune system to fight cancer cells however cancer cells can avoid detection and continue to grow. Cancer cells will release substances that create dominance against Th-2 and make the body less able to fight cancer cells. 
Decreased activation in Th1 will decrease the Th1 stimuli against IL-2 proliferation that will decrease the efficiency of immune response resistance to cancer cells. Stimulation at ST36 acupuncture points can activate neurotransmitters in the brain. At stellar stimulation cell level ST36 can induce the synthesis of nitric oxide (NO) enzyme in keratinocytes. Skin cells that produce NO neurotransmitters will send signals through the spinal cord to the brain, stimulating the HPA to release endogenous opioid neurotransmitters ( $\beta$-endorphins), to locations containing immune cells.

The stimulator activates Th1 and increases the production of IL-2. resulting in increased lymphocytes, increased NK cell activation, production and enhancement of cytokine products that have tumorisidal properties or cytolytic activity against tumor cells, thereby directly suppressing tumor growth. The study showed that acupuncture stimulation in ST36 Zusanli, BL18 Ganshu, BL20 Pishu stimulates the formation of $\beta$-endorphins, and $\beta$-endorphins affect the proliferation of lymphocytes by increasing mitosis of $\mathrm{T}$ cells. B-endorphins also play an indirect role in stimulating macrophages to produce IL-1 and stimulates $\mathrm{T}$ lymphocytes to produce IL-2, which induces an increase in NK cell expression, thus causing an increase in NK cell sitolytic activity. ${ }^{29,30}$ The above research data explain that EA $2 \mathrm{~Hz}$ has an immunomodulatory effect by increasing the percentage of lymphocytes which further increases immune surveillance in $\mathrm{C} 3 \mathrm{H}$ mice breast adenocarcinoma model.This occurs because the low frequency $E A$ action induces the release of $\beta$ - endorphins through stimulation of HPA axis. $\beta$-endorphins stimulate lymphocyte proliferation by increasing $T$ cell mitosis. $\beta$-endorphins also play an indirect role in stimulating macrophages to produce IL(interleukin)-1 and stimulate $T$ lymphocytes to produce IL-2, thus strengthening anticancer immune function. ${ }^{31,32}$

\section{Conclusion}

This study performed research on acupuncture incancer management and provided good result. Therefore acupuncture, in particular electroacupuncture, proved to be beneficial in improving immunity by affecting lymphocyte enhancement. Acupuncture can be considered as adjuvant therapy in breast cancer patients.

\section{Abbreviations}

APC: Antigen Presenting Cells; ANS: autonomic nervous system; CTL: cytotoxic T lymphocytes; EA: electroacupuncture; GLOBOCAN: Global Burden Of Cancer;
HPAthe hypothalamicpituitaryadrenal; IARC: International Agency for Research on Cancer; IFN- $\gamma$ : Interferon-gama; IL: Interleukin; KPD: breast cancer; NK cell: Natural Killer Cell;NO: nitric oxide; PBS: peripheral blood smear; Riskesdas: Basic Health Research; RSCM: Dr. Hospital. Cipto Mangunkusumo; Th: T helper lymphocytes; TSA: tumor-specific antigen; WHO: World Health Organization.

\section{Acknowledgements}

We would like to acknowledge all staffs of Department of Medical Acupuncture, Faculty of Medicine, University of Indonesia, and Department of Histology, Faculty of Medicine, University of Indonesia..

\section{Funding}

There was no funding support.

\section{Availability of data and materials \\ Not applicable}

\section{Authors's contributions}

RK, HM, AS, ACB participated in the design of this study. RK, HM, AS, ACB participated in the concept of this study. RK and ACB performed histological examination. RK, HM, HBTA performed draft the manuscript.

\section{Competing interests}

The authors declared no competing interests.

\section{Consent for publication}

Not applicable

\section{Ethics approval}

PT. Bimana Indomedical animal care and use committee ethical committee approve this study.

\section{REFERENCES}

1. RI Kemenkes. InfoDATIN : STOP KANKER. Kementerian Kesehatan RI Pusat Data dan Informasi. 2015. http://www. depkes.go.id/resources/download/pusdatin/infodatin/ infodatin-kanker.pdf

2. Zelig U, Barlev E, Bar O, Gross I, Flomen F, Mordechai S, et al. Early detection of breast cancer using total biochemical analysis of peripheral blood components: a preliminary study. BMC cancer. 2015;15(408):1-10.

3. Wahidin M. Deteksi Dini Kanker Leher Rahim dan Kanker Payudara di Indonesia 2007-2014. Buletin Jendela Data dan Informasi Kesehatan 2015;1:1-15. http://www.depkes.go. id/download.php?file.../buletin/buletin-kanker.pdf 
4. Prayitno A, Sari A, Wahyuningsih L, Fitria MS, Astirin OP, Mudigdo A, et al. Lymphocytes CD8+ Expression Mean Increases the Immunity against Cancer. Journal of Immune Based Therapies, Vaccines and Antimicrobials. 2014;3:37-41. http://dx.doi.org/10.4236/jibtva.2014.34006

5. Mayor DF. Electroacupuncture A Practical Manual and Resource. Churchill Livingstone.Elsevier. 2007.

6. Lee M. Acupuncture and Immune Modulation. The Nyu Langone Online Journal of Medicine. 2015. https://www. clinicalcorrelations.org/? $p=8293$

7. Kim SK, Lee $\mathrm{Y}$, Cho H, Koo S, Choi SM, Shin MK, et al. A Parametric Study on the Immunomodulatory Effects of Electroacupuncture in DNP-KLH Immunized Mice. Hindawi Publishing Corporation Evidence-Based Complementary and Alternative Medicine. 2010;2010:1-5. http://dx.doi. org/10.1093/ecam/nep166

8. Mihardja H, Suwarsa O, Sujatno RM, Sudarmono PP, Mose JC. The Effect of Electroacupuncture at ST36, BL18 and BL20 Acupuncture Points on Interferon Gamma Level, Mitosis, Apoptosis and Tumor Mass in C3H Mice Model With Breast Adenocarcinoma and its Correlation with the number of Interventions. International Journal of Current Advanced Research . 2017;6(12).

9. Budiono BP. Pengaruh Pemberian Echinacea Terhadap Sebukan Limfosit Dan Sekresi Perforin Sel Mononuklear Pada Mencit Dengan Adenokarsinoma Payudara Yang Diberi Stres. [Tesis] Program Pasca Sarjana Magister Ilmu Biomedik Dan Program Pendidikan Dokter Spesialis 1 Ilmu Bedah Universitas Diponegoro Semarang. 2008.

10. Nugraha G. Panduan Pemeriksaan Laboratorium Hematologi. Jakarta. Trans Info Media. 2015.

11. Chien TJ, Liu CY, Hsu CH. Integrating Acupuncture into Cancer Care. J Tradit Complement Med. 2013;3(4):234-9.

12. Duck HK, Na JP, McArdle T. Cancer-Specific Stress andMood Disturbance: Implications for Symptom Perception, Quality of Life, and Immune Response inWomen Shortly after Diagnosis of Breast Cancerlnternational Scholarly Research Network.2012;2012:1-7.

13. Zhang C, Franklin T, Sarkar DK. Inhibition of mammary cancer progression in fetal alcohol exposed rats by $\beta$-endorphin neurons. Alcohol Clin Exp Res. 2016 Jan; 40(1): 134-140.

14. Liu LJ, Guo CJ, Jiao XM. Effect of acupuncture on immunologic function and histopathology of transplanted mammary cancer in mice. Zhongguo Zhong Xi Yi Jie He Za Zhi. 1995 Oct;15(10):615-7.

15. Baratawidjaja KR, Rengganis I. Imunologi Dasar. Jakarta. Balai Penerbit FKUI. 2009.

16. Kresno SB. Imunologi: Diagnosis dan Prosedur Laboratorium. Jakarta. Balai Penerbit FKUI. 2010.

17. Wang $\mathrm{H}$, Pan $\mathrm{Yi}$, Xue $\mathrm{B}$,Wang $\mathrm{X}$, Zhao $\mathrm{F}$, Jia J, Liang $X$, Wang $X$. The Antioxidative Effect of Electro-Acupuncture in a Mouse Model of Parkinson's Disease. PLoS One. 2011; 6(5): e19790.
18. Komite Nasional Penanggulangan Kanker (KPKN). Panduan nasional penatalaksanaan kanker payudara.Kementerian Kesehatan Republik Indonesia, 2015

19. Fedewa SA, Sauer AG, Siegel RL, Jemal A. Prevalence of Major Risk Factors and Use of Screening Tests for Cancer in the United States. AACRJournal. 2015;24(4).

20. Zhu X, Bensoussan A, McNicol ED, Chen H, Lu W. Acupuncture for treatment-related side effects in women with breast cancer (protocol). Cochrane Database of Systematic Reviews 2013(5).

21. Yamaguchi N, Takahashi T, Sakuma M. Acupuncture regulates leukocyte subpopulations in human peripheral blood.Evid Based Complement Alternat Med. 2007 Dec; 4(4): 447-453.

22. ArranzL, Guayerbas N, Siboni L, Fuente M De la. Effect of acupuncture treatment on the immune function impairment found in anxious women. Am J Chin Med. 2007;35(1):35-51.17. Sadikin M. Biokimia Darah. Jakarta. Widiya Medika. 2002.

23. Cho WCS. Acupuncture and Moxibustion as an Evidencebased Therapy for Cancer. ACAM. 2012;3.

24. Mori H, Nishijo K, Kawamura H, Abo T. Unique immunomodulation by electro-acupuncture in humans possibly via stimulation of the autonomic nervous system. Neurosci Lett. 2002 Mar 1;320(1-2):21-4

25. Yim YK, Lee $H$, Hong $K E$, Kim YI, Lee BR, Son $C G$, et al. Electro-acupuncture at acupoint ST36 reduces inflammation and regulates immune activity in Collagen-Induced Arthritic Mice. Evid Based Complement Alternat Med. 2007 Mar;4(1):51-7

26. Park MH, Hong JT. Roles of NF-kB in Cancer and Inflammatory Diseasesand Their Therapeutic Approaches. Cells. 2016 Mar 29;5(2).

27. Lee SJ, Kim MD, Kim SH. Immunomodulating Activity of BL 18 (Ganshu) Acupuncture on the Experimental Liver Metastasis Model of Mice. Korean Journal Oriental Physiologi and Pathology. 2007;2(3):760-4.

28. Xiao Y, Xie Z, Shao Z, Chen W, Xie H, Qin G, et al. Neutrophil and lymphocyte counts at diagnosis are associated with overall survival of pancreatic cancer $A$ retrospective cohort study. Medicine (Baltimore). 2016 Oct;95(40):e5024.

29. Rahmah AA, Agoes A, Yuliatun L. Peran Elektro-Akupuntur terhadap Perbedaan Kadar IL-2 pada Tikus Putih (Rattus norvegicus) Galur Wistar yang Diinduksi DMBA. Majalah Kesehatan FKUB. 2015 Dec; 2(4): 207.

30. ZhangW, ZhangY, MaX, ChenY. Effects of acupuncturing Pishu combined with Ginsenoside Rg3 on the immune function of rats with chronic fatigue. Int J Clin Exp Med. 2015; 8(10): 19022-19029.

31. Pais I, Correia N, Pimentel I, Teles MJ, Neves E, Vasconcelos $\mathrm{J}$, et al. Effects of Acupuncture on Leucopenia, Neutropenia, NK, and B Cells in Cancer Patients: A Randomized Pilot Study. Evid Based Complement Alternat Med. 2014;2014:21739 
30 The Effect of Electroacupunture on the Percentage of Lymphocyte Count on the Peripheral Blood Smear of C3H Mice Breast Adenocarcinoma Model 23-30

32. Gilman SC, Schwartz JM, Milner RJ, Bloom FE, Feldman JD. Beta-Endorphin enhances lymphocyte proliferative responses (neuropeptides/mitogens/lymphocyte activation/ opiates/stress). Proc Natl Acad Sci USA. 1982;79:4226-30.
33. Bartlett K. Chinese Medicine Improves Blood Cell Counts for Cancer Patients. 2011. https://www.care2.com/ greenliving/chinese-medicine-improves-blood-cell-countsfor-cancer-patients.html 